\title{
CHLORIDE-DEPENDENT ENHANCEMENT BY BARBITURATES OF $\gamma$-AMINOBUTYRIC ACID RECEPTOR BINDING ${ }^{1}$
}

\author{
RICHARD W. OLSEN ${ }^{2}$ AND ADELE M. SNOWMAN
}

Division of Biomedical Sciences and Department of Biochemistry, University of California, Riverside, California 92521

Received March 16, 1982; Revised June 3, 1982; Accepted June 4, 1982

\begin{abstract}
Barbiturates enhance GABA receptor (sodium-independent) binding at $0^{\circ} \mathrm{C}$ to bovine brain membranes about 2-fold in chloride-containing buffer but not in chloride-free phosphate or Tris/ citrate buffer. This effect is observed in frozen and thawed, thoroughly washed membranes from various regions of bovine brain as well as washed membranes prepared from unfrozen rat cerebral cortex; it is destroyed by brief treatment of the membranes with the detergent Triton X-100. The enhancement is concentration-dependent, with approximately $250 \mu \mathrm{M}$ pentobarbital giving $50 \%$ of the maximal effect seen with saturating $2 \mathrm{~mm}$ barbiturate. This effect is reversed by the GABA chloride channel-blocking drug picrotoxinin in a concentration-dependent manner, with $50 \%$ inhibition at $0.6 \mu \mathrm{M}$, and also by GABA receptor antagonists, such as bicuculline, which inhibit base line GABA receptor binding. Under similar conditions, benzodiazepines do not perturb GABA binding. The barbiturate enhancement varies with brain region in a manner which does not correlate with overall GABA receptor binding; for example, cerebellum shows poor barbiturate enhancement despite a high level of GABA binding. The anions which support barbiturate interactions with GABA receptor binding in vitro are the same ones shown to be required for barbiturate interactions with benzodiazepine receptor binding (Leeb-Lundberg, F., A. Snowman, and R. W. Olsen (1980) Proc. Natl. Acad. Sci. U. S. A. 77: 7468-7472) and correlated with the permeation of GABAregulated, barbiturate-enhanced inhibitory ion channels measured in vivo. Likewise, the activity of a series of barbiturates to enhance GABA binding shows a specificity and stereospecificity agreeing with that shown for enhancing benzodiazepine binding and correlating with pharmacological activity as nervous system depressants and enhancers of GABA responses. However, the activity of excitatory barbiturates remain to be clarified. These results suggest that there is a receptor site for barbiturates on the GABA - benzodiazepine receptor -chloride ion channel complex, consistent with physiological enhancement of GABA postsynaptic responses by barbiturates. The enhancement of GABA binding by barbiturates appears to involve an increase in the number of binding sites under most assay conditions and using several labeled receptor ligands. The amount of GABA bound to both high and low affinity subpopulations is increased by barbiturates in both equilibrium and kinetic measurements. It is possible that the effect of barbiturates involves an increase in affinity for normally undetectable low affinity $\left(K_{D} \geq 1 \mu \mathrm{M}\right)$ GABA sites. Low affinity sites are detected under some conditions, and the barbiturate enhancement is then consistent with an increased affinity. Barbiturates enhance GABA binding in a similar manner at $37^{\circ} \mathrm{C}$ and $0^{\circ} \mathrm{C}$, but the effect is much greater at $37^{\circ} \mathrm{C}$ than at $0^{\circ} \mathrm{C}$ for the analogue piperidine-4-sulfonic acid. This may be related to the differential interactions of GABA analogues with benzodiazepine receptors at different temperatures. The more physiological conditions of temperature and saline appear to be more suitable for physiologically relevant receptor binding studies in vitro.
\end{abstract}

Barbiturates have central nervous system depressant activity which seems to be due primarily to a potentiation of inhibitory synaptic transmission mediated by $\gamma$-aminobutyric acid (GABA) (Haefely et al., 1979; Huang and

This work was supported by National Science Foundation Grant BNS 80-19722, National Institutes of Health Grants NS 12422 and RR05816, Research Career Development Award NS-00224, and a grant
Barker, 1980; Nicoll and Wojtowicz, 1980), although inhibition of both excitatory synaptic transmission and voltage-regulated ionic currents also is observed with

from Hoffmann-LaRoche, Inc. We wish to thank Dr. Fredrik LeebLundberg for helpful discussions.

${ }^{2}$ To whom correspondence should be addressed at the Division of Biomedical Sciences, University of California, Riverside, CA 92521. 
these drugs (Richards, 1972, Blaustein, 1968). Barbiturates enhance the postsynaptic membrane response to GABA (Huang and Barker, 1980; Schulz and Macdonald, 1981; Simmonds, 1981), which involves a receptor-regulated chloride channel opening (Study and Barker, 1981). The action of another important group of nervous system depressants, the benzodiazepines, also may involve potentiation of GABA-mediated inhibition (Haefely et al., 1979; Study and Barker, 1981).

GABA receptor sites can be assayed in vitro by suitable radioactive ligand binding (Olsen et al., 1981b). GABA receptors have been assayed traditionally in $\mathrm{NaCl}$-free medium (Zukin et al., 1974; to prevent GABA uptake) and in frozen and thawed, thoroughly disrupted, and multiply washed membranes (Enna and Snyder, 1975; to remove endogenous inhibitors of GABA binding (Greenlee et al., 1978) including GABA (Napias et al., 1980), but possibly other materials (Guidotti et al., 1978)). Under the assay conditions usually employed, barbiturates and benzodiazepines were observed neither to inhibit nor to perturb GABA receptor binding (Olsen et al., 1979), suggesting that the receptors for both of these classes of drugs are distinct from the GABA receptor site.

Benzodiazepines also can be assayed in vitro by radioactive ligand binding (Squires and Braestrup, 1977), and benzodiazepine binding is enhanced allosterically in affinity by both GABA agonists (Tallman et al., 1980) and barbiturates (Leeb-Lundberg et al., 1980) and the related drugs, the anxiolytic pyrazolopyridines (Leeb-Lundberg et al., 1981a; Supavilai and Karobath, 1981). The enhancement of benzodiazepine receptor binding by barbiturates is chemically specific and stereospecific, with potencies of a series of compounds correlating well with pharmacological activity as depressants and potentiators of GABAergic inhibition (Bowery and Dray, 1978). Barbiturate and pyrazolopyridine enhancement of benzodiazepine binding is inhibited competitively by the GABA chloride channel-blocking convulsant drug picrotoxinin (Leeb-Lundberg et al., 1980, 1981a) and indirectly inhibited by the GABA receptor antagonist bicuculline (Leeb-Lundberg et al., 1981a). Furthermore, the interaction of barbiturates (Leeb-Lundberg et al., 1980) and pyrazolopyridines (Supavilai and Karobath, 1981) with benzodiazepine receptors is dependent on the presence of chloride or certain other anions. These anions happen to be the same anions which can permeate membrane chloride channels in spinal cord (Araki et al., 1961) and brain neurons (Eccles et al., 1977) which are involved in GABAergic postsynaptic inhibitory potentials and which are potentiated by barbiturates (Nicoll et al., 1975). The drug interactions in vitro are consistent with the existence of a receptor complex which includes receptors for GABA, benzodiazepines, and barbiturates as well as the chloride channel (Olsen, 1981).

Pyrazolopyridines increase GABA receptor binding in vitro in a chloride-enhanced manner (Placheta and Karobath, 1980). The pyrazolopyridines have been shown to perturb benzodiazepine binding at a picrotoxinin-sensitive site which is similar to or identical to the site at which barbiturates perturb benzodiazepine binding (Leeb-Lundberg et al., 1981a). Like the barbiturates (Ticku and Olsen, 1978), the pyrazolopyridines (LeebLundberg et al., 1981a) competitively inhibit the binding of $\left[{ }^{3} \mathrm{H}\right]$ dihydropicrotoxinin at relevant concentrations. Thus, pyrazolopyridines and barbiturates appear to have numerous in vitro actions in common, and therefore, barbiturates also might be expected to perturb GABA binding. Barbiturates have now been observed to enhance GABA binding; initial studies suggest that a gentle membrane preparation is critical for observing this interaction (Willow and Johnston, 1980, 1981a, b, c). We present here the results of studies on barbiturate enhancement of GABA receptor binding and the conclusion that this effect is optimal in the presence of chloride or certain other anions which are able to permeate GABAregulated chloride channels as mentioned above. This anion specificity further supports the relevance of the barbiturate receptor sites defined by these in vitro effects, both to the GABA receptor-ionophore complex and to the pharmacological actions of barbiturates. Some of the results have been presented in preliminary form (Olsen et al., 1981a; Olsen and Leeb-Lundberg, 1981). While this paper was in preparation, a report describing similar results appeared (Asano and Ogasawara, 1981).

\section{Materials and Methods}

$\left[{ }^{3} \mathrm{H}\right] \mathrm{GABA}(50 \mathrm{Ci} / \mathrm{mmol})$ was purchased from Amersham Corp; $\left[{ }^{3} \mathrm{H}\right]$ muscimol $(10.3 \mathrm{Ci} / \mathrm{mmol}),\left[{ }^{3} \mathrm{H}\right]$ piperidine-4-sulfonic acid (P4S; $35 \mathrm{Ci} / \mathrm{mmol}),\left[{ }^{3} \mathrm{H}\right]$ isoguvacine $(24.8 \mathrm{Ci} / \mathrm{mmol})$, and $\left[{ }^{3} \mathrm{H}\right] 4,5,6,7$-tetrahydroisoxazolo $[5,4$ c]pyridine-3-ol (THIP; $24.3 \mathrm{Ci} / \mathrm{mmol}$ ) were purchased from New England Nuclear. Unlabeled muscimol and P4S were gifts of Dr. P. Krogsgaard-Larsen, Copenhagen. Pentobarbital, 5-ethyl, 5-[1,3-dimethylbutyl] barbituric acid (DMBB), amobarbital, and secobarbital were gifts of Eli Lilly and Co. Barbital was a gift of Merck; etazolate was a gift of E. R. Squibb \& Sons, Inc; mephobarbital and phenobarbital were gifts of Sterling-Winthrop; metharbital was a gift of Abbot Laboratories. Stereoisomers of hexobarbital and mephobarbital were kindly provided by Dr. J. Knabe, Saärbrucken. All other compounds were from commercial sources.

Preparation of synaptic membranes. Mammalian brain membranes were prepared and assayed for GABA receptor binding essentially as described previously (Greenlee et al., 1978; Napias et al., 1980; Olsen et al., 1981b; Krogsgaard-Larsen et al., 1981). Various brain regions from rat (freshly prepared) or cow (frozen in 0.32 M sucrose for up to 6 months at $-20^{\circ} \mathrm{C}$ ) were homogenized in $10 \mathrm{vol}$ of $0.32 \mathrm{M}$ sucrose at $0^{\circ} \mathrm{C}$ by eight passes of a motor-driven Teflon pestle ( $800 \mathrm{rpm})$ in a glass homogenizer tube (Thomas). The homogenate was centrifuged for $10 \mathrm{~min}$ at $1000 \times \mathrm{g}$ in a Beckman centrifuge (J2-21) to yield a crude nuclear pellet, which was discarded. The supernatant fraction was centrifuged for $60 \mathrm{~min}$ at $150,000 \times g$ to collect the crude mitochondrial, synaptosomal, and microsomal membranes, and this time, the supernatant was discarded. This membrane fraction was disrupted twice with a Tissumizer (Ultra-Turrax, Tekmar Co., Cincinnati, $\mathrm{OH}$ ) in $20 \mathrm{vol}$ of distilled water and centrifuged at $150,000 \times \mathrm{g}$ for $30 \mathrm{~min}$. The resulting pellet was homogenized in $50 \mathrm{~mm}$ Tris buffer adjusted to $\mathrm{pH}$ 7.1 at $4^{\circ} \mathrm{C}$ with sodium-free citric acid and frozen at $-20 \mathrm{C}^{\circ}$. These samples were thawed and centrifuged, homogenized in the same buffer, and then frozen again. On the day of the assay, the samples were thawed and 
centrifuged. The pellets were homogenized in the buffer to be used for assays and centrifuged once more, and the resulting pellets were homogenized for assay.

Binding assays. GABA receptor binding was measured by centrifugation (Enna and Snyder, 1975; Olsen et al., 1981b; Greenlee et al., 1978) in $\mathrm{Na}^{+}$-free buffer systems, $50 \mathrm{~mm}$ Tris/citrate ( $\mathrm{pH}$ 7.1) or phosphate/chloride buffer $\left(20 \mathrm{~mm} \mathrm{KH}_{2} \mathrm{PO}_{4} / \mathrm{K}_{2} \mathrm{HPO}_{4}\right.$ containing $50 \mathrm{~mm} \mathrm{KCl}$, pH 7.5). $\left[{ }^{3} \mathrm{H}\right]$ GABA (4 nM), $\left[{ }^{3} \mathrm{H}\right]$ muscimol (1 nM), $\left[{ }^{3} \mathrm{H}\right] \mathrm{P} 4 \mathrm{~S}$ (5 $\mathrm{nM})$, or $\left.{ }^{3} \mathrm{H}\right]$ isoguvacine $(10 \mathrm{nM})$ was added with or without $0.1 \mathrm{~mm}$ nonradioactive ligands to estimate nondisplaceable binding; in some experiments, the concentration of radiolabeled ligand was varied. Varying concentrations of barbiturates were included in the assays. Triplicate samples of about $1 \mathrm{mg}$ of protein in an assay volume of $1 \mathrm{ml}$ were incubated for $15 \mathrm{~min}$ at 0 to $4^{\circ} \mathrm{C}$, followed by centrifugation at $50,000 \times g$ for $10 \mathrm{~min}$ in a Beckman centrifuge (J2-21). The supernatants were discarded and the pellets were rinsed twice superficially with $3 \mathrm{ml}$ of cold buffer. Rinsed pellets were solubilized overnight in $0.20 \mathrm{ml}$ of Soluene 350 (Packard). Radioactivity was counted (Beckman LS-3155T) in $3 \mathrm{ml}$ of toluene containing $0.5 \%(\mathrm{w} / \mathrm{v})$ of 2,5-diphenyloxazole, with an efficiency of $27 \%$. Protein was measured according to the method of Lowry et al. (1951). The binding data were analyzed by a nonlinear regression program, using a HP3000 computer to determine affinity constants $\left(K_{D}\right.$ values) and the quantity of binding sites $\left(B_{\max }\right)$. The best fits of the data to receptor models, consisting of one binding site or two or three independent sites (Olsen et al., 1981b), were compared.

Kinetic experiments. Experiments were performed using $20 \mathrm{~mm} \mathrm{KH} \mathrm{KH}_{4} / \mathrm{K}_{2} \mathrm{HPO}_{4}$ buffer containing $50 \mathrm{~mm}$ $\mathrm{KCl}(\mathrm{pH}$ 7.5). Quadruplicate samples of about $1 \mathrm{mg}$ of protein in an assay volume of $1 \mathrm{ml}$ containing $20 \mathrm{nM}$ of radioactive ligand were treated as described below. For measurement of the association rate (on rate), bovine cortex membranes were incubated at $0^{\circ} \mathrm{C}$ for various periods. The membranes were pelleted by centrifugation for 3 min at 12,800 $\times g$ in an Eppendorf microcentrifuge (model 5412). The dissociation rates (off rate) were measured by equilibration of bovine cortex membranes with radioactive ligand for at least $15 \mathrm{~min}$ at $0^{\circ} \mathrm{C}$, after which the incubation media were made $0.1 \mathrm{~mm}$ in the corresponding nonradioactive ligand $(10-\mu \mathrm{l}$ aliquots in the 1$\mathrm{ml}$ assay volumes) and then centrifuged after further incubation for appropriate times as described above. Background was determined at equilibrium ( $\geq 15 \mathrm{~min}$ ) with $0.1 \mathrm{~mm}$ of nonradioactive ligand. The bulk of the membranes were pelleted within a few seconds, so that the accuracy of the time scale was about $\pm 10 \mathrm{sec}$; the variation of the counts per min in any 15 -sec period (after the first $15 \mathrm{sec}$ of dissociation) was less than $5 \%$. The pellets were rinsed superficially, solubilized overnight in $0.1 \mathrm{ml}$ of Soluene 350 , and counted as described above.

In some experiments, filtration was employed to separate the bound ligand from free ligand. Membranes were prepared as described above and incubated with radioactive GABA receptor ligands for various times (association rate measurements) or equilibrated for at least 15 min, followed by the addition of a microliter volume of excess nonradioactive ligand for various times (dissociation rate measurements). The samples in quadruplicate were trapped on Whatman GF/B filter paper discs under vacuum and washed with $2 \mathrm{ml}$ of $0.2 \mathrm{M} \mathrm{NaCl}$ at $0^{\circ} \mathrm{C}$. The filters were dried and radioactivity was measured in $5 \mathrm{ml}$ of New England Nuclear Aquasol:toluene (2:1) with an efficiency of $45 \%$. Background, determined with $0.1 \mathrm{~mm}$ nonradioactive GABA, was 30 to $40 \%$.

\section{Results}

Barbiturates such as pentobarbital showed a concentration-dependent enhancement of sodium-independent GABA receptor binding in well washed, frozen and thawed membrane fractions of bovine cerebral cortex when using assay buffers containing chloride ions. The enhancement reached a maximum of roughly $100 \%$ in the presence of $50 \mathrm{mM} \mathrm{KCl}$ with an apparent $\mathbf{E C}_{50}$ value for pentobarbital of $250 \mu \mathrm{M}$ (Fig. $1 A$ ). The effect of pentobarbital was reversed in a concentration-dependent manner by picrotoxinin with an $\mathrm{IC}_{50}$ value of $0.8 \mu \mathrm{M}$ (Fig. $1 B$ ). Picrotoxinin at concentrations over $1 \mu \mathrm{M}$ also showed a weak inhibition of base line GABA binding under these assay conditions. The picrotoxinin-like convulsant isopropyl bicyclophosphate and the benzodiazepine RO53663 at $0.1 \mathrm{~mm}$ also completely blocked the effect of 250 $\mu \mathrm{M}$ pentobarbital; as with base line GABA binding, the pentobarbital-enhanced GABA binding also was blocked by bicuculline and strychnine with $\mathrm{IC}_{50}$ values of $100 \mathrm{nM}$ and $10 \mu \mathrm{M}$, respectively (data not shown).

Table I summarizes the effects of several drugs on GABA receptor binding to various brain membrane preparations assayed under various conditions. As reported previously (Olsen et al., 1979), there was no effect of pentobarbital $(500 \mu \mathrm{M})$ on GABA binding when assayed in Tris/citrate buffer devoid of sodium chloride. Similarly, there were no significant, concentration-dependent, and reproducible effects on GABA binding measured in Tris/citrate buffer in the presence of the anxiolytic pyrazolopyridine etazolate $(10 \mu \mathrm{M})$, the barbiturate DMBB $(200 \mu \mathrm{M})$, or the benzodiazepine flurazepam $(10 \mu \mathrm{M})$ (Table I, line 1). The barbiturates produced a weak inhibition of GABA binding. In Tris/citrate, these agents had no effects on the binding dissociation rate (data not shown), measured as previously described (Olsen et al., 1981b; Krogsgaard-Larsen et al., 1981). Furthermore, in Tris/citrate, there was not significant perturbation by $500 \mu \mathrm{M}$ pentobarbital or $10 \mu \mathrm{M}$ flurazepam of GABA binding curves measured at 20 ligand concentrations (Table II). Other brain regions gave similar results.

In an assay buffer containing chloride ions, there was significant enhancement of GABA or muscimol binding by pentobarbital, DMBB, and etazolate but not flurazepam (Table I, lines 2 and 3). Flurazepam weakly inhibited GABA binding ( $\leq 20 \%$ at $10 \mu \mathrm{M}$, but this effect was not seen with another benzodiazepine, diazepam). There was no enhancement of GABA binding by benzodiazepines under any of the assay conditions tested. Inclusion of both pentobarbital and flurazepam together gave enhancement equal to that of pentobarbital alone (3 experiments). GABA receptor binding also was enhanced by pentobarbital but not by flurazepam in other brain regions (Table I, lines 4, 5, and 6). Pentobarbital enhancement gave a maximum effect of $110 \%$ over base line (210\% of control, or 2.1-fold) in cortex, $90 \%$ in hippocampus, $50 \%$ in striatum and thalamus, but only $20 \%$ in 

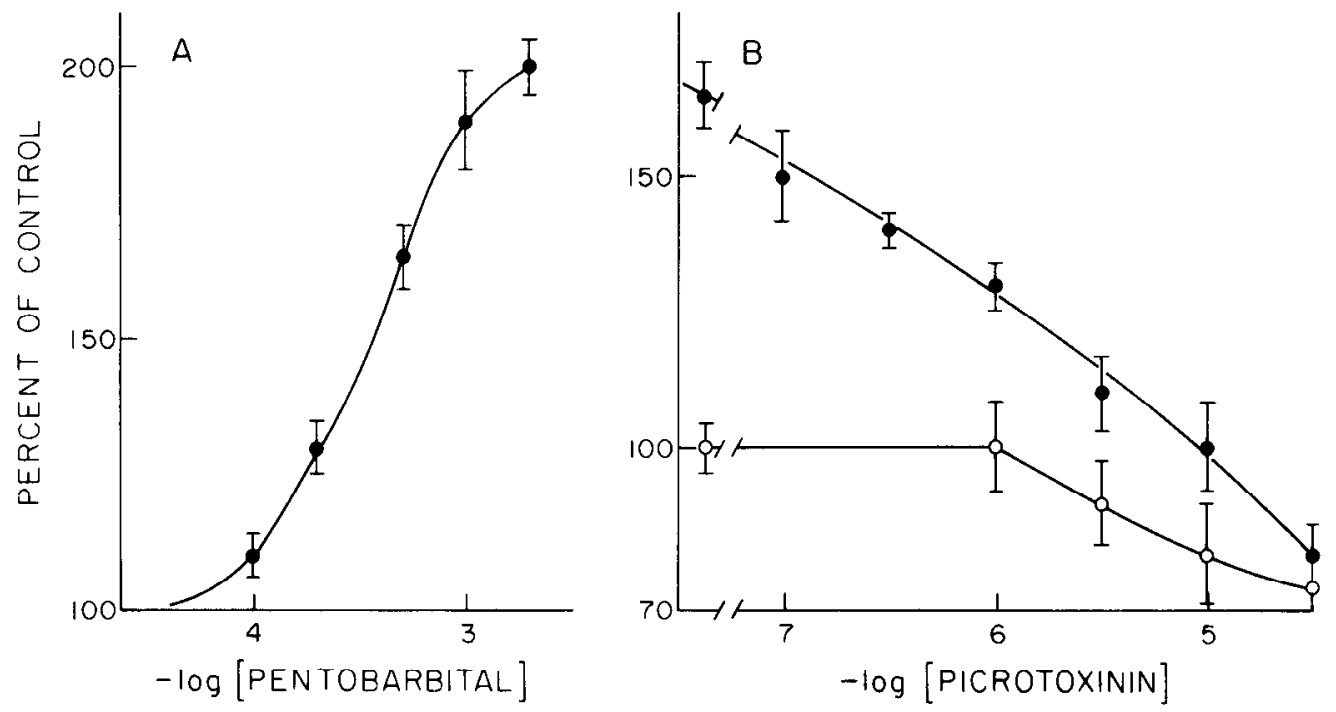

Figure 1. A, Effect of pentobarbital concentration on GABA receptor binding; $B$, Reversal by picrotoxinin of pentobarbitalenhanced GABA binding. The binding of $\left[{ }^{3} \mathrm{H}\right] \mathrm{GABA}$ to well washed, frozen and thawed bovine cortex membranes was measured by centrifugation as described under "Materials and Methods." Assays in triplicate were performed at $0^{\circ} \mathrm{C}$ using $2.5 \mathrm{nM}$ GABA in $20 \mathrm{~mm}$ potassium phosphate buffer, $\mathrm{pH} 7.5$, with $50 \mathrm{~mm} \mathrm{KCl}$. Standard errors of the mean are indicated in the figure. The results are typical of 3 experiments which varied $\leq 2 \%$. In this experiment, the nondisplaceable background, which was determined in the presence of $0.1 \mathrm{rnM}$ nonradioactive GABA, was $950 \pm 10 \mathrm{cpm}$. Specific binding, determined by subtracting the background from the total counts per min pelleted with the membranes, was $1982 \pm 99 \mathrm{cpm}$. This is equal to $68 \%$ displaceable binding and a signal:noise ratio of 2.1 for the control situation (in the absence of barbiturates or picrotoxinin).

TABLE I

Drug interactions with $G A B A$ receptor binding using varying assay conditions, membrane preparations, brain regions, and ligands

Specific binding was assayed by centrifugation, determining background (nondisplaceable binding) with 0.1 mM nonradioactive GABA. The numbers in parentheses after the assay conditions refer to the number of experiments in triplicate from which the means \pm SEM were determined. The numbers in parentheses under the data refer to the percentage of enhancement $(\uparrow)$ or inhibition $(\downarrow)$.

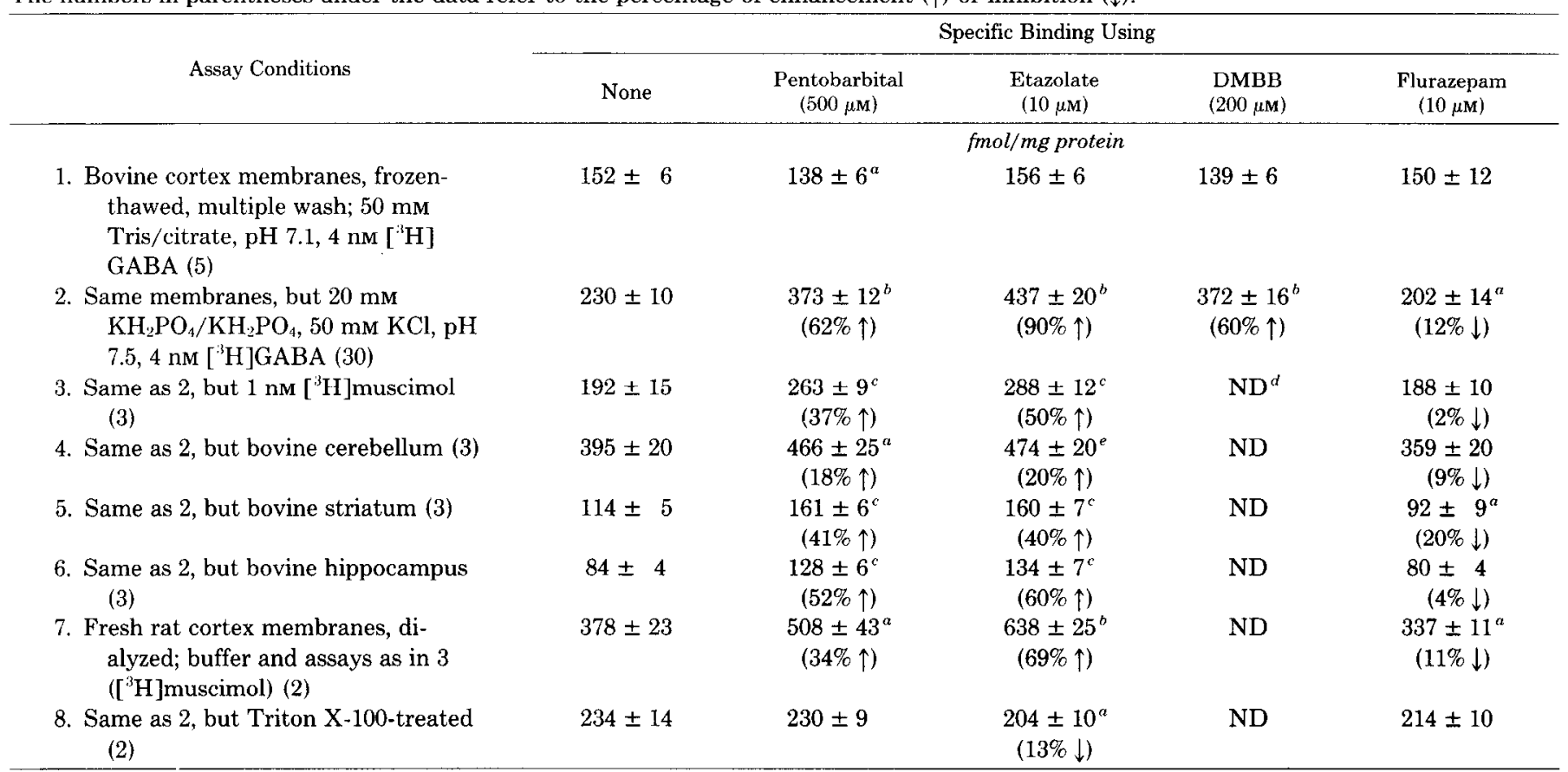

" $p<0.05$, calculated by the $t$ test.

${ }^{b} p<0.001$, calculated by the $t$ test.

" $p<0.005$, calculated by the $t$ test.

"ND, not determined.

${ }^{\circ} p<0.01$, calculated by the $t$ test.

cerebellum and brainstem. The magnitude of this effect did not correlate with overall GABA binding, which is highest in cerebellum (Greenlee et al., 1978), nor with barbiturate-displaceable $\left[{ }^{3} \mathrm{H}\right]$ dihydropicrotoxinin binding (Leeb-Lundberg et al., 1981c). Neither did it correlate with base line benzodiazepine binding nor with barbitu- 
TABLE II

Concentration-dependent binding parameters for $G A B A$ receptor sites assayed in the absence and presence of barbiturates and benzodiazepines

\begin{tabular}{|c|c|c|c|c|c|}
\hline $\begin{array}{l}\text { Tissue, Ligand, and Assay } \\
\text { Conditions }\end{array}$ & $K_{D 1}$ & $B_{\max 1}$ & $K_{m 2}$ & $B_{\max 2}$ & Total $B_{\max }$ \\
\hline & $n M$ & $\begin{array}{c}\text { pmol/ } \\
m g\end{array}$ & $\overline{n M}$ & & $\mathrm{~mol} / \mathrm{mg}$ \\
\hline \multicolumn{6}{|l|}{$\begin{array}{c}\text { A. Bovine cortex, Tris/cit- } \\
\text { rate, } 0^{\circ} \mathrm{C},\left[{ }^{3} \mathrm{H}\right] \mathrm{GABA}\end{array}$} \\
\hline 1. Control & 10 & 0.3 & 250 & 1.9 & 2.2 \\
\hline 2. Pentobarbital $(500 \mu \mathrm{M})$ & 9 & 0.3 & 200 & 1.8 & 2.1 \\
\hline 3. Flurazepam $(10 \mu \mathrm{M})$ & 7 & 0.3 & 175 & 2.1 & 2.4 \\
\hline \multicolumn{6}{|l|}{ 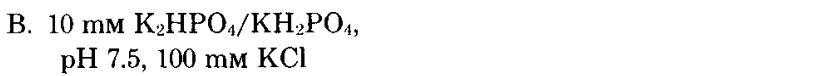 } \\
\hline 1. Control & 5 & 0.25 & 150 & 1.5 & 1.75 \\
\hline 2. Pentobarbital & 6 & 0.5 & 200 & 2.0 & 2.5 \\
\hline 3. Flurazepam & 7 & 0.2 & 180 & 1.5 & 1.7 \\
\hline \multicolumn{6}{|l|}{ C. Same as $\mathrm{B}$, but $37^{\circ} \mathrm{C}$} \\
\hline 1. Control & 30 & 0.4 & 240 & 1.8 & 2.2 \\
\hline 2. Pentobarbital & 20 & 0.7 & 190 & 2.3 & 3.0 \\
\hline \multicolumn{6}{|l|}{$\begin{array}{l}\text { D. Same as B, but bovine } \\
\text { striatum }\end{array}$} \\
\hline 1. Control & 7 & 0.2 & 200 & 1.0 & 1.2 \\
\hline 2. Pentobarbital & 10 & 0.4 & 200 & 1.3 & 1.7 \\
\hline \multicolumn{6}{|l|}{ E. Same as B, but $\left[{ }^{3} \mathrm{H}\right] \mathrm{P} 4 \mathrm{~S}$} \\
\hline 1. Control & 15 & 0.15 & 200 & 1.0 & 1.2 \\
\hline 2. Pentobarbital & 15 & 0.25 & 250 & 1.1 & 1.4 \\
\hline \multicolumn{6}{|l|}{ F. Same as $\mathrm{E}$, but $37^{\circ} \mathrm{C}$} \\
\hline 1. Control & 7 & 0.1 & 150 & 1.1 & 1.2 \\
\hline 2. Pentobarbital & 15 & 0.5 & 200 & 1.6 & 2.1 \\
\hline \multicolumn{6}{|l|}{$\begin{array}{l}\text { G. Same as B, but }\left[{ }^{3} \mathrm{H}\right] \text { mus- } \\
\text { cimol }\end{array}$} \\
\hline 1. Control & 3 & 0.4 & 20 & 2.2 & 2.6 \\
\hline $\begin{array}{l}\text { 2. Pentobarbital } \\
\text { (one-site fit) }\end{array}$ & $\begin{array}{c}4 \\
(8)\end{array}$ & $\begin{array}{c}0.8 \\
(2.4)\end{array}$ & 15 & 2.0 & 2.8 \\
\hline \multicolumn{6}{|l|}{$\begin{array}{l}\text { H. Same as } B \text {, but }\left[{ }^{3} \mathrm{H}\right] \text { iso- } \\
\text { guvacine }\end{array}$} \\
\hline 1. Control & 5 & 0.1 & 200 & 1.3 & 1.4 \\
\hline 2. Pentobarbital & 15 & 0.4 & 300 & 1.7 & 2.1 \\
\hline
\end{tabular}

rate enhancement of benzodiazepine binding, which was about the same (percentage) in all brain regions (LeebLundberg et al., 1980; Leeb-Lundberg and Olsen, 1981; Olsen and Leeb-Lundberg, 1981). Interestingly, the brain regional variation correlated with that fraction of pentobarbital-enhanced benzodiazepine binding which could be blocked by bicuculline (Leeb-Lundberg and Olsen, 1981). The results shown in Table I are the average of numerous observations. However, in $8 \%$ of membrane preparations, considerably lower (about 50\%) pentobarbital enhancement of GABA binding was seen, and in $4 \%$ of membrane preparations, a large effect (about 200\%) was seen. We also have noticed considerable variation in the extent of this effect between animal species (F. LeebLundberg, A. M. Snowman, and R. W. Olsen, unpublished observations).

Table II and Figure 2 show that GABA receptor binding assayed in different brain regions with different radioactive ligands is enhanced by pentobarbital throughout the GABA receptor ligand concentration range, with an apparent increase in the number of binding sites, $B_{\max }$ (discussed below).

The binding of $\left[{ }^{3} \mathrm{H}\right]$ muscimol to fresh (unfrozen) rat cortex membranes, osmotically shocked and dialyzed extensively at $0^{\circ} \mathrm{C}$ against Tris/citrate buffer to remove endogenous GABA, was measured in phosphate/chloride buffer. Both pentobarbital and etazolate were observed to enhance binding in this (chloride-containing) medium ('l'able I, line 7). Flurazepam slightly inhibited GABA receptor binding.

The effect of pentobarbital on GABA receptor binding was lost, however, upon treatment of frozen bovine brain membranes with $0.05 \%$ Triton X-100 for $30 \mathrm{~min}$ at $37^{\circ} \mathrm{C}$, followed by washing the membranes and assay in phosphate/chloride buffer at $0^{\circ} \mathrm{C}$ (Table I, line 8).

Table III shows that the half-maximal effect of chloride ions on the pentobarbital enhancement of GABA binding occurred at approximately $30 \mathrm{~mm}$, with at least $100 \mathrm{~mm}$ $\mathrm{Cl}^{-}$needed for maximal activation. The ion requirements for barbiturate enhancement of GABA binding are described in Table IV. As in the case of barbiturate enhancement of benzodiazepine binding (Leeb-Lundberg et al., 1980), the effect requires certain anions, such as chloride, bromide, iodide, perchlorate, thiocyanate, or nitrate, whereas others, such as sulfate, acetale, and propionate, will not substitute. Sodium, potassium, calcium, or magnesium salts of the active anions (e.g., chloride) were effective, but none of these cations was effective with an inactive anion (e.g., sulfate).

The activity of several barbiturates to enhance GABA binding is shown in Table V. Comparison to those barbiturates active in enhancing benzodiazepine binding (Leeb-Lundberg and Olsen, 1982a) again shows a very similar specificity, including a marked stereospecificity for the $N^{1}$-methyl barbiturates, such as hexobarbital. The more potent CNS depressant drugs $(+)$-hexobarbital and $(-)$-mephobarbital are much more active in the in vitro binding studies than the pharmacologically less active (-)-hexobarbital and (+)-mephobarbital (Knabe et al., 1978). Phenobarbital gave no enhancement of GABA binding under these conditions. At high concentrations, it inhibited GABA binding weakly ( $20 \%$ at $1 \mathrm{~mm}$ ).

Table II summarizes the data for GABA receptor binding as a function of ligand concentration for different brain regions, using several radioactive ligands. Binding to GABA receptors was enhanced by pentobarbital, assayed with $\left[{ }^{3} \mathrm{H}\right]$ GABA, $\left[{ }^{3} \mathrm{H}\right]$ muscimol, $\left[{ }^{3} \mathrm{H}\right] \mathrm{P} 4 \mathrm{~S},\left[{ }^{3} \mathrm{H}\right]$ isoguvacine, or $\left[{ }^{3} \mathrm{H}\right]$ THIP (data not shown). Table II and Figure 2 indicate that pentobarbital causes an apparent increase in the number of binding sites detected or $B_{\max }$ value. In the typical example shown in Figure $2 A$, the binding of $\left[{ }^{3} \mathrm{H}\right] \mathrm{GABA}$ depicted in a Scatchard plot gives the binding parameters listed in Table IIB. Nonlinear regression computer analysis of the data gives a best fit for two binding sites as previously described (Olsen et al., 1981b). Pentobarbital-enhanced GABA binding also gives a two-site fit, with similar affinities $\left(K_{l}\right)$ values are 5 and $150 \mathrm{~nm}$ in control and 6 and $200 \mathrm{~nm}$ with pentobarbital present), but shows an increase in $B_{\max }$ from 0.25 to $0.50 \mathrm{pmol} / \mathrm{mg}$ of protein for the higher affinity population and an increase from 1.5 to $2.0 \mathrm{pmol} / \mathrm{mg}$ for the lower affinity population, giving an overall increase from 1.75 to $2.50 \mathrm{pmol} / \mathrm{mg}$ of protein. In 10 experiments, control 


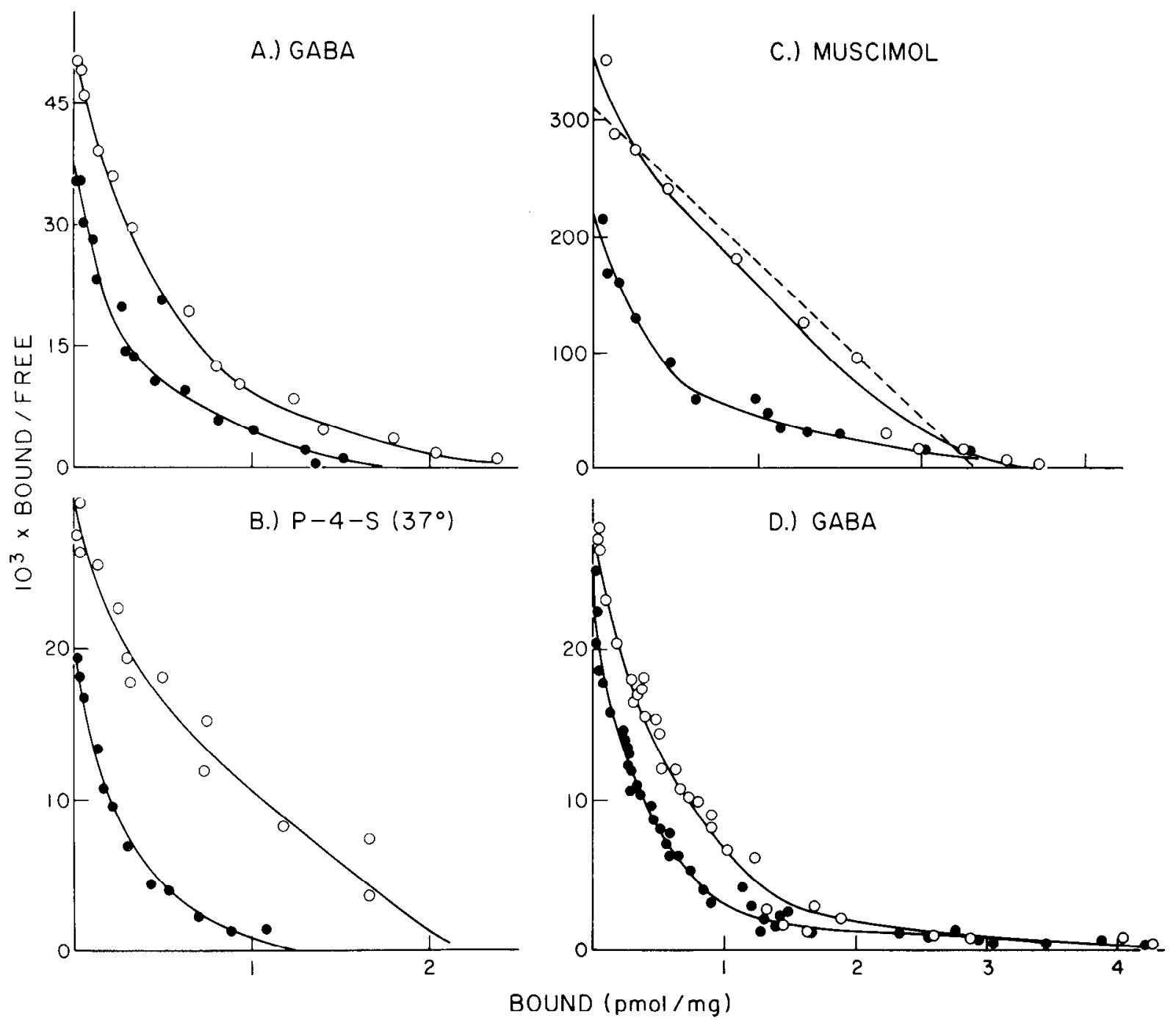

Figure 2. Effect of pentobarbital on the binding of radioactive GABA receptor ligands to bovine cortex membranes at $0^{\circ} \mathrm{C}$ in phosphate/chloride buffer. All assays were carried out as described under "Materials and Methods." Triplicate assays containing radioactive ligand were performed as indicated, with background being determined with 0.1 mM nonradioactive GABA ( $A$ and $D), 0.1 \mathrm{~mm}$ nonradioactive $\mathrm{P} 4 \mathrm{~S}(B)$, and $10 \mu \mathrm{M}$ nonradioactive muscimol $(C)$. In each case, the solid circles represent the binding as a function of ligand concentration assayed in the absence of pentobarbital, while the open circles represent the same binding determined in the presence of $500 \mu \mathrm{M}$ pentobarbital. Experiments $A, C$, and $D$ were performed at $0^{\circ} \mathrm{C}$ and experiment $B$ was performed at $37^{\circ} \mathrm{C}$. Details are given for the ligand concentrations employed in experiment $D$ as an example: the concentration of radioactive GABA was varied from 0.3 to $10 \mathrm{nM}$ at 10 concentration points, using $0.1 \mathrm{~mm}$ nonradioactive GABA at each point to determine the background; then the concentration of nonradioactive GABA was varied using constant radioactive GABA at 10 nM. Some representative values obtained were as follows. At $0.6 \mathrm{nM}, 628 \mathrm{cpm} \pm 3 \%$ of total ligand "binding" was measured; 176 $\mathrm{cpm} \pm 4 \%$ of background was determined; the difference of $452 \mathrm{cpm} \pm 4 \%$ represents specific binding, corresponding to $72 \%$ displacement and a ratio of specific binding to background of 2.6. At $10 \mathrm{~nm}$ GABA, the total "binding" was $6683 \mathrm{cpm} \pm 4 \%$ and the background was $1932 \mathrm{cpm} \pm 6 \%$; the specific binding therefore was $4751 \mathrm{cpm} \pm 6 \%$, corresponding to $71 \%$ displaceable binding and a signal:noise ratio of 2.5 ; at a concentration of approximately $10 \mu \mathrm{M} \mathrm{GABA}$, total counts were $2360 \mathrm{cpm} \pm 6 \%$ and background was $1932 \mathrm{cpm} \pm 6 \%$, with a difference of specific binding of $428 \mathrm{cpm} \pm 6 \%$, representing $18 \%$ displaceable binding and a signal:noise ratio of 0.22 . Such values of specific binding were significantly different from zero. Data were analyzed by nonlinear regression as previously described (Olsen et al., 1981 b), giving less weight to those points having a large variance in the mean.

binding $K_{D}$ values (average $K_{D 1}$ and $K_{D z}$ values were 10 \pm 3 and $250 \pm 100 \mathrm{nM}$ ) were not raised or lowered consistently by pentobarbital; $B_{\max }$ values (average $B_{\max 1}$ and $B_{\max } 2$ values were $0.3 \pm 0.1$ and $1.7 \pm 0.5$ $\mathrm{pmol} / \mathrm{mg}$ ) were increased in every case by $70 \pm 40 \%$ for both populations of sites in the presence of pentobarbital. In 6 experiments, flurazepam showed no enhancement under these conditions.

The apparent increase in $B_{\max }$ for GABA receptor binding in the presence of pentobarbital is even more evident when using $\left[{ }^{3} \mathrm{H}\right] \mathrm{P} 4 \mathrm{~S}$ as the ligand, in which case the binding at $37^{\circ} \mathrm{C}$ is increased by pentobarbital from 1.2 to $2.1 \mathrm{pmol} / \mathrm{mg}$ (Fig. $2 B$; Table IIF), or $\left[{ }^{3} \mathrm{H}\right]$ isoguvacine (1.4 to $2.1 \mathrm{pmol} / \mathrm{mg}$, Table IIH). In the case of $\left[{ }^{3} \mathrm{H}\right]$ muscimol binding, however (Fig. 2C; Table IIG), the pentobarbital enhancement seems more consistent with an increasc in affinity rather than in $B_{\max }$. The apparently different effects on various GABA receptor ligands by 
TABLE III

Chloride dependence of pentobarbital enhancement of GABA receptor binding

For these experiments, the control background was $1,451 \pm 73 \mathrm{cpm}$, total binding was $5,632 \pm 169 \mathrm{cpm}$, and specific binding was $4,181 \pm 169$ cpm $(15,485 \mathrm{dpm}, 139.51 \mathrm{fmol})$. These results are the mean of four experiments each in triplicate.

\begin{tabular}{|c|c|c|c|}
\hline \multirow[b]{2}{*}{ Assay Buffer } & \multicolumn{2}{|c|}{ Specific Binding } & \multirow{2}{*}{$\begin{array}{c}\text { Fold } \\
\text { Enhance- } \\
\text { ment }\end{array}$} \\
\hline & Control & $\begin{array}{l}\text { Pentobar- } \\
\text { bital }\end{array}$ & \\
\hline & \multicolumn{2}{|c|}{ fmol/mg protein" } & \\
\hline $\begin{array}{l}\text { 1. } 10 \mathrm{mM} \mathrm{K}_{2} \mathrm{HPO}_{4} / \mathrm{KH}_{2} \mathrm{PO}_{4}, \mathrm{pH} 7.5 \\
\text { Plus KCl }\end{array}$ & $140 \pm 6$ & $126 \pm 9$ & 0.9 \\
\hline 2. $10 \mathrm{mM}$ & $131 \pm 12$ & $157 \pm 15$ & 1.2 \\
\hline 3. $20 \mathrm{mM}$ & $122 \pm 6$ & $158 \pm 9^{b}$ & 1.3 \\
\hline 4. $50 \mathrm{mM}$ & $107 \pm 6$ & $181 \pm 12^{\circ}$ & 1.7 \\
\hline 5. $100 \mathrm{mM}$ & $91 \pm 6$ & $181 \pm 12^{c}$ & 2.0 \\
\hline 6. $200 \mathrm{mM}$ & $71 \pm 6$ & $159 \pm 9^{6}$ & 2.25 \\
\hline
\end{tabular}

"Assayed at $4 \mathrm{~nm}\left[{ }^{3} \mathrm{H}\right] \mathrm{GABA}$ as in Table I and Figure 1.

${ }^{\prime} p<0.01$, significantly different from control.

$p<0.002$, significantly different from control.

TABLE IV

Anion specificity of pentobarbital enhancement of GABA receptor binding

GABA binding and the percentage of enhancement were determined as described in Table I. Anions were included as $50 \mathrm{mM} \mathrm{K}^{+}$salt in 10 mM $\mathrm{KPO}_{4}$ buffer, $\mathrm{pH} 7.5$ (the hase line medium). The percentage of control was calculated from the sodium-independent GABA receptor binding measured in the same buffer and ionic strength in the presence of $500 \mu \mathrm{M}$ pentobarbital, divided by the binding in its absence, $\times 100$. Results are the average of 3 experiments in triplicate. In addition to the results shown, $\mathrm{Na}^{+}, \mathrm{Ca}^{2+}$, and $\mathrm{Mg}^{2+}$ salts of chloride, but not sulfate, supported enhancement.

\begin{tabular}{lc}
\hline \multicolumn{1}{c}{ Anion } & Percentage of Control \\
\hline $\mathrm{Cl}^{-}$ & $164 \pm 2$ \\
$\mathrm{Br}^{-}$ & $166 \pm 3$ \\
$\mathrm{I}$ & $160 \pm 3$ \\
$\mathrm{ClO}_{4}^{-}$ & $182 \pm 4$ \\
$\mathrm{SCN}^{-}$ & $188 \pm 4$ \\
$\mathrm{NO}_{3}^{-}$ & $158 \pm 3$ \\
$\mathrm{SO}_{4}^{2-}$ & $101 \pm 3$ \\
$\mathrm{CH}_{3} \mathrm{COO}^{-}$ & $96 \pm 4$ \\
$\mathrm{CH}_{3} \mathrm{CH}_{2} \mathrm{COO}^{-}$ & $98 \pm 3$
\end{tabular}

pentobarbital may be related to different levels of binding sites detected with these ligands. Thus, the control $B_{\max }$ values for $\left[{ }^{3} \mathrm{H}\right] \mathrm{P} 4 \mathrm{~S}$ and $\left[{ }^{3} \mathrm{H}\right]$ isoguvacine seem to be slightly lower than that for $\left[{ }^{3} \mathrm{H}\right] \mathrm{GABA}$, and that for $\left[{ }^{3} \mathrm{H}\right]$ muscimol is even higher $(2.5 \mathrm{pmol} / \mathrm{mg}$ in bovine cortex $)$. $\left[{ }^{3} \mathrm{H}\right]$ Muscimol, to a greater extent than $\left[{ }^{3} \mathrm{H}\right] \mathrm{GABA}$ or $\left[{ }^{3} \mathrm{H}\right] \mathrm{P} 4 \mathrm{~S}$, labels low affinity sites which are difficult to detect due to $K_{D}$ values in the $1 \mu \mathrm{M}$ range. In the presence of pentobarbital the total number of sites detected is approximately the same for all ligands.

Further evidence for low affinity GABA binding is provided by a 40-point binding curve for $\left[{ }^{3} \mathrm{H}\right] \mathrm{GABA}$ in the absence and presence of pentobarbital (Fig. $2 D$ ). This shows significant binding in the 0.1 to $10 \mu \mathrm{M}$ concentration range and a total $B_{\max }$ of about $4 \mathrm{pmol} / \mathrm{mg}$. It should be noted that all of the specific GABA binding depicted in Figure $2 D$ is displaceable not only by $0.1 \mathrm{~mm}$ nonradioactive GABA but also by $10 \mu \mathrm{M}$ muscimol, $100 \mu \mathrm{M}$ $\mathrm{P} 4 \mathrm{~S}$, and $100 \mu \mathrm{M}$ bicuculline; that is, it has receptor-like specificity (Olsen et al., 1979). Under these experimental conditions, where low affinity sites are detectable in the absence of barbiturates, there is no further increase in $B_{\max }$ when barbiturates are added, and the increased binding appears to be due to an increase in binding affinity. The computer fit of these expanded binding curves is equally good for three sites ( $K_{D}$ values of 10 $\mathrm{nM}, 50 \mathrm{nM}$, and $2 \mu \mathrm{M}$; standard deviation, 0.96) and for two sites $\left(K_{D}\right.$ values of $20 \mathrm{~nm}$ and $400 \mathrm{nM}$; standard deviation, 0.98 ) (without pentobarbital). In the presence of pentobarbital, at least two sites also are needed to fit the GABA binding data, with less binding in the micromolar range and more in the 10 to $100 \mathrm{~nm}$ range. However, the fit for muscimol binding with pentobarbital (Fig. $2 C$; Table IIG) is almost as good statistically for one site ( $K_{D}$ $=8 \mathrm{nM} ; B_{\max }=2.4 \mathrm{pmol} / \mathrm{mg}$ ) as it is for two sites, which is also consistent with a shift to high affinity population(s). Thus, the additional GABA receptor binding seen in the presence of pentobarbital involves sites with affinities in the 1 to $100 \mathrm{nM}$ range, similar or perhaps identical in affinity to those seen in the absence of barbiturates.

The kinetics of GABA receptor binding also are consistent with the equilibrium data. As we reported previously (Olsen et al., 1981b), association and dissociation rates for GABA are biphasic, with slow on and off rates (half-lives of 1 to $4 \mathrm{~min}$ ) corresponding to the higher affinity binding sites and more rapid rates (half-lives less than $5 \mathrm{sec}$ ) corresponding to lower affinity binding sites. Likewise, biphasic kinetics for $\left[{ }^{3} \mathrm{H}\right] \mathrm{P} 4 \mathrm{~S}$ binding are observed (Krogsgaard-Larsen et al., 1981). Figure 3 shows the dissociation rates for $\left[{ }^{3} \mathrm{H}\right]$ muscimol (Fig. $3 A$ ) and $\left[{ }^{3} \mathrm{H}\right] \mathrm{P} 4 \mathrm{~S}$ (Fig. $3 B$ ) binding to bovine cortex membranes at $0^{\circ} \mathrm{C}$. The dissociation rates for the slow component of $\left[{ }^{3} \mathrm{H}\right] \mathrm{GABA}$ (half-life $=3.5 \mathrm{~min}$, not shown) and $\left[{ }^{3} \mathrm{H}\right] \mathrm{P} 4 \mathrm{~S}$ (half-life $=0.8 \mathrm{~min}$ ) binding were not altered significantly in the presence of pentobarbital. The dissociation rate for the slow component of $\left[{ }^{3} \mathrm{H}\right]$ muscimol binding, however, was increased slightly by pentobarbital, decreasing the control half-life from 11.5 to $8 \mathrm{~min}$ (Fig. $3 A$ ). In addition to the slow component, a second component

TABLE V

Activities of barbiturates $(500 \mu \mathrm{M})$ on benzodiazepine and $G A B A$ receptor binding

$\left[{ }^{3} \mathrm{H}\right] \mathrm{GABA}$ binding was measured by centrifugation as described under "Materials and Methods" with $2.5 \mathrm{~nm}$ GABA. $\left[{ }^{3} \mathrm{H}\right]$ Diazepam binding results are from Leeb-Lundberg and Olsen (1982a). The results are the mean of three determinations.

\begin{tabular}{lcc}
\hline \multirow{2}{*}{ Compound } & \multicolumn{2}{c}{ Percentage of Control" } \\
\cline { 2 - 3 } & {$\left[{ }^{3} \mathrm{H}\right]$ Diazepam } & {$\left[{ }^{3} \mathrm{H}\right] \mathrm{GABA}$} \\
\hline ( \pm )-DMBR & $219 \pm 5$ & $243 \pm 7$ \\
( \pm -Secobarbital & $197 \pm 4$ & $177 \pm 4$ \\
( \pm )-Pentobarbital & $185 \pm 3$ & $175 \pm 2$ \\
Amobarbital & $158 \pm 2$ & $137 \pm 2$ \\
(+)-Hexobarbital & $169 \pm 2$ & $174 \pm 3$ \\
(-)-Hexobarbital & $119 \pm 1$ & $108 \pm 2$ \\
(-)-Mephobarbital & $163 \pm 2$ & $143 \pm 3$ \\
(+)-Mephobarbital & $102 \pm 2$ & $100 \pm 3$ \\
Phenobarbital & $106 \pm 3$ & $90 \pm 3$ \\
( \pm )-Metharbital & $103 \pm 2$ & $98 \pm 3$ \\
Barbital & $103 \pm 2$ & $100 \pm 1$ \\
\hline
\end{tabular}

"Percentage of control refers to the binding of either radioactive diazepam or GABA measured at a constant radioligand concentration in the presence of $0.5 \mathrm{~mm}$ pentobarbital, divided by the binding in its absence, $\times 100$. 

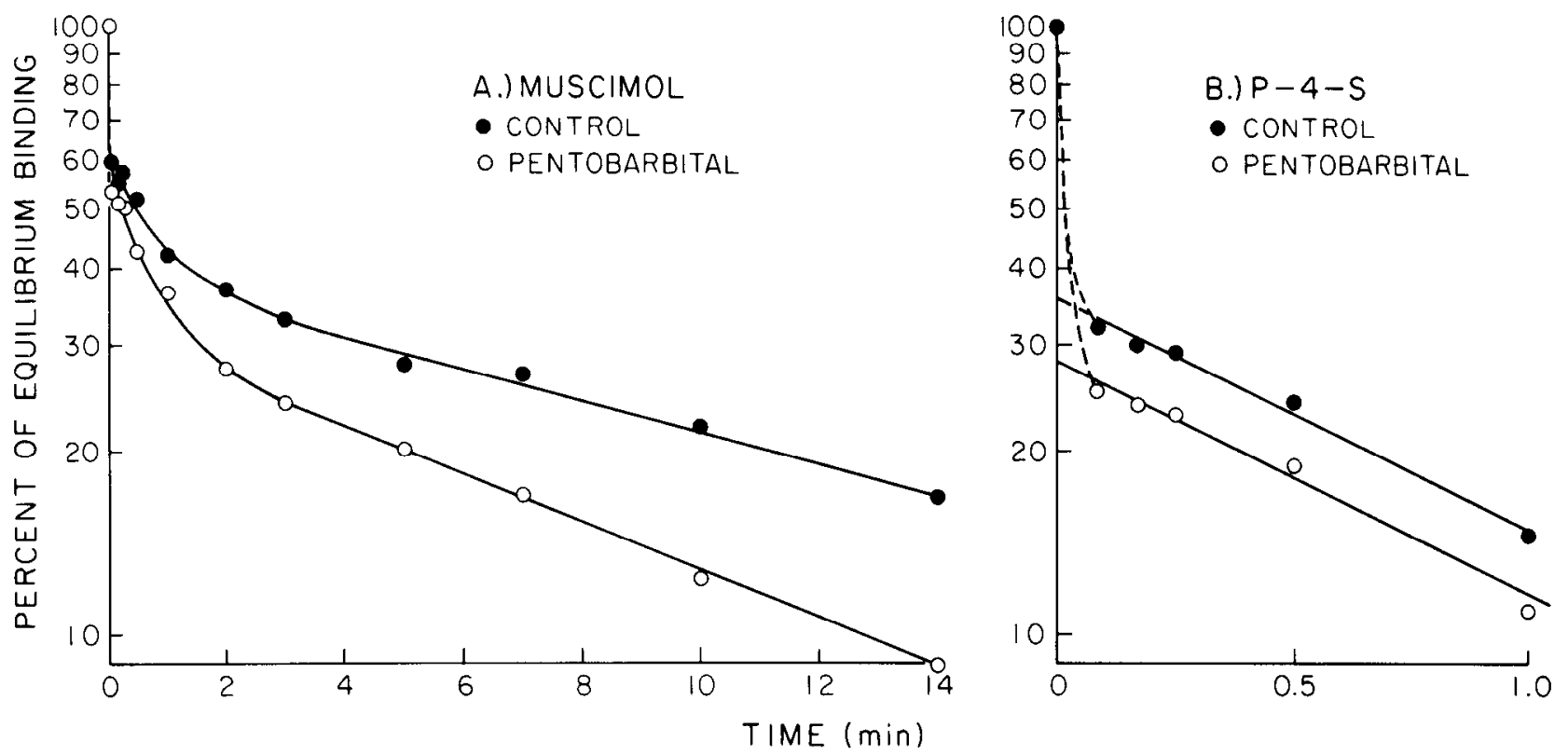

Figure 3. Effect of pentobarbital on the dissociation rate for GABA receptor ligands. $A$, muscimol; $B$, P1S. The off rate for GABA receptor ligands was measured by the microcentrifugation method as described under "Materials and Methods." Bovine cortex membranes equilibrated at $0^{\circ} \mathrm{C}$ with radioactive ligand for 15 min or longer were made $0.1 \mathrm{~mm}$ in nonradioactive GABA at time zero and samples were centrifuged at varying times thereafter to determine the dissociation of bound ligand in the presence $(\bigcirc)$ and absence $(O)$ of $500 \mu \mathrm{m}$ pentobarbital. Note that the values are normalized to the percentage of equilibrium values.

was evident, showing a half-life on the order of 10 to 30 sec. The higher affinity ligand, muscimol, apparently has a dissociation rate for the "lower affinity" sites which is slightly slower than that for GABA and P4S. This rate constant still could not be measured accurately by the microcentrifuge method employed, due to an uncertainty of about $10 \mathrm{sec}$ in the actual time of quenching. Even allowing for this uncertainty in the early time points, the faster component did not appear to extrapolate through the $100 \%$ (zero time) point, suggesting additional binding to a third component which has completed the dissociation reaction in less than $5 \mathrm{sec}$. This very rapidly dissociating component could correspond to the "very low" affinity sites evident in the equilibrium data shown in Figure 2, $C$ and $D$. Filtration assays were employed, but the amount of binding was about $30 \%$ lower than that observed with centrifugation, due to loss of rapidly dissociating bound ligand during filter washing. The binding which was retained by filtration was about $80 \%$ slowly dissociating component as compared to about $50 \%$ in the centrifugation assays. Thus, the more rapid dissociation rates could not be measured, but it was possible to determine that some rapidly dissociating ligand was already lost at the first measurable time, 2 to $3 \mathrm{sec}$ after the addition of excess nonradioactive ligand.

The data in Figure 3 are normalized and the actual binding is almost 2-fold greater in the presence of pentobarbital. Therefore, more binding to the slower component occurs when pentobarbital is present, but the ratio of slow to fast components decreases slightly (from $39 \%$ to $32 \%$ for muscimol and from $35 \%$ to $28 \%$ for $\mathrm{P} 4 \mathrm{~S}$ ), because an even greater increase in the amount of binding to the faster component(s) has occurred. Under these conditions of low ligand concentration, the effect of barbiturate is an apparent increase in the number of binding sites $\left(B_{\max }\right)$ detected for both slow and fast components, as described above. Since the proportion of slow sites did not increase, there could have been no conversion of detectable fast sites into slow sites by pentobarbital. The additional binding to slowly dissociating sites apparently arises from previously undetectable sites. On the other hand, the increase in binding seen with pentobarbital does not involve only fast sites; if it had, the ratio of fast to slow would have increased even more.

This conclusion is supported further by calculating the percentage of enhancement of muscimol binding by pentobarbital at various times during association and dissociation in an experiment such as that shown in Figure 3. In the off direction, using an example where pentobarbital induced an $80 \%$ enhancement at equilibrium (zero time), this enhancement fell to $40 \%$ at the first time point ( 5 to $10 \mathrm{sec}$ ) following the addition of excess nonradioactive ligand, indicating that a greater fraction of the enhanced binding showed rapid dissociation than slow dissociation. On the other hand, some enhanced binding also showed slow dissociation, as indicated by the retention of $25 \%$ enhancement after $2 \mathrm{~min}$ of dissociation, a time when only slow component remains. Likewise, in the on direction, there was considerable enhancement $(50 \%)$ at $5 \mathrm{sec}$ (indicating increased binding primarily to the rapid, low affinity component) but even more enhancement $(70 \%)$ at 1 to $2 \mathrm{~min}$ (indicating increased binding to the slow, high affinity component in addition).

Finally, the effect of temperature on the pentobarbital enhancement was examined. Measuring GABA receptor binding at $37^{\circ} \mathrm{C}$ did not result in any significant changes over parameters determined at $0^{\circ} \mathrm{C}$ (Table II, B and C). There is a slight shift to lower affinities (higher $K_{D}$ values) for the $37^{\circ} \mathrm{C}$ curves, but two components are still the best fit. Pentobarbital did not affect GABA or mus- 
cimol binding differently at the two temperatures. However, $\left[{ }^{3} \mathrm{H}\right] \mathrm{P} 4 \mathrm{~S}$ binding was more enhanced at $37^{\circ} \mathrm{C}$ than at $0^{\circ} \mathrm{C}$ (Table II, E and F), reaching $400 \%$ of control at some ligand concentrations.

\section{Discussion}

Consistent with physiological evidence that barbiturates enhance GABA-mediated inhibition in the nervous system (Haefely et al., 1979) and biochemical evidence that barbiturates perturb benzodiazepine binding in vitro to receptor sites which are coupled to GABA receptor sites (Olsen, 1981), barbiturates also directly perturb the binding of GABA receptor ligands. This in vitro interaction was not observed in previous studies using frozen and thawed, thoroughly washed membranes and Tris/ citrate buffer lacking sodium and chloride ions (Olsen et al., 1979). Barbiturate enhancement of GABA binding in the NaCl-free Tris/citrate buffer was observed with fresh brain membranes prepared with a more gentle procedure (Willow and Johnston, 1980). We present evidence here that barbiturate enhancement of GABA binding is optimal in the presence of physiological concentrations of chloride ions or certain other anions. This interaction is observed with both fresh membranes and frozen and thawed, thoroughly washed membranes (a procedure whose primary purpose is to remove endogenous GABA from the preparation; Napias et al., 1980). The "gentle" membrane preparation employed by Willow and Johnston $(1980,1981 \mathrm{c})$ might involve retention of some endogenous chloride ions or might, for some other reason, show a less absolute requirement for chloride in the barbiturate-GABA receptor interaction.

Barbiturates increase GABA binding to sites having affinities and kinetics similar to those normally detected in the absence of barbiturates, with $K_{D}$ values in the 10 to $200 \mathrm{nM}$ range and dissociation rate half-times in the seconds to minutes range. We cannot say for certain whether these "new" sites are the same as or different from those previously described. The "new" sites appear to arise from an increased affinity of GABA binding sites which are normally undetectable (Fig. $2, A$ and $B$ ) or perhaps from sites which are barely detectable (Fig. 2, $C$ and $D$ ), having $K_{D}$ values for GABA in the micromolar range and kinetic rates too fast to measure by available techniques. The effect of pentobarbital appears to be an increase in $B_{\max }$ under conditions where these low affinity sites are not detectable in the control assays.

The enhanced binding of GABA seen with barbiturates was described by Willow and Johnston (1981b) as a decreased dissociation rate for GABA binding to an already slowly dissociating subpopulation, consistent with an increase in affinity for the high affinity subpopulation of GABA receptor binding sites (Willow, 1981). In our hands, the barbiturate enhancement appears to involve an increase in the number of binding sites showing very slow (minutes) and slow (seconds) dissociation rates, corresponding to affinities in the 1 to $100 \mathrm{~nm}$ range. The increase in slowly dissociating (and associating) GABA binding would be consistent with measurements of the chloride ion channels opened by GABA (Study and Barker, 1981), showing that barbiturates prolong the lifetime of these channels. A reasonable model would equate the time that the chloride channel is open with the time during which the GABA receptor is occupied.

Interestingly, in the same study (Study and Barker, 1981), benzodiazepines enhanced the frequency of opening rather than the lifetime of GABA-activated chloride channels. Under the same conditions where barbiturates enhanced GABA binding, no significant effects of benzodiazepines were observed, perhaps consistent with the apparent physiological differences in action of the two classes of drugs. Of course, the two drug categories also have other differences in pharmacological action despite the apparent similarities in their involvement with the GABA system. It is also possible that the benzodiazepines perturb a subpopulation of low affinity GABA binding sites which are normally undetectable, and the perturbation is not great enough to make these hypothetical sites detectable. We observed no significant effect of benzodiazepines on GABA binding, even under conditions of high ligand concentration where low affinity sites are detected. In addition, we observed no significant alteration by benzodiazepines of the barbiturate effect on GABA binding, when both drugs were included concurrently. However, this interaction probably is very dependent on the method of membrane preparation and assay. The original report (Guidotti et al., 1978) of benzodiazepine effects on GABA binding was observed only with unwashed membranes suggested to contain a protein which modulated the interactions and which could be removed by thorough washing. Recently, however, several groups have reported enhancement of GABA receptor binding using a variety of membrane preparations (Meiners and Salama, 1982; Ito and Kuriyama, 1982; Skerritt et al., 1982; Matsumoto and Fukuda, 1982). In all cases, the effects were quite small, and these reports do not agree on which GABA binding sites are affected, the first two describing increased affinity for high affinity sites of less than 1.5-fold and the last two describing an increased affinity for the low affinity sites of less than 2fold. Ito and Kuriyama (1982) reported that the enhancement persists in detergent-soluble extracts. The difference between these results and those of Guidotti et al. (1978) (who observed an increase in the $B_{\max }$ of high affinity sites) and ours (no effect) are unexplained at this time.

The specificity of the barbiturate interaction with GABA receptor binding sites is shown by the chemical specificity and stereospecificity for a series of barbiturates, by the reversal of this effect by picrotoxinin and related convulsants, and by the stimulation of the effect by those anions which are capable of permeating GABA receptor-linked chloride ion channels. As with nervous system depressant action, the potency of a series of barbiturates to enhance GABA binding correlates well with lipid solubility. Thus, the hydrophobic portion of the nerve cell membrane, probably including the fatty acid chains of phospholipids, appears to be involved in the structures which barbiturates must affect in exerting their pharmacological actions as well as their effects on GABA receptor binding. These hydrophobic regions may form the actual site of action ("receptor") for the barbiturates and/or they could form part of the pathway through which the barbiturates must travel to reach their 
site of action. The site of barbiturate action on GABA binding, as in nervous system depression, could involve lipids but also probably involves protein, due to the stereospecificity of the effect. With the $N^{1}$-methyl barbiturates, the hypnotic isomers (+)-hexobarbital and $(-)$-mephobarbital are more potent enhancers of GABA binding than their pharmacologically less active isomers.

Furthermore, the interaction of barbiturates with GABA receptor binding (Stephenson and Olsen, 1982) and benzodiazepine binding (Stephenson et al., 1982; Davis and Ticku, 1981) is preserved in bile salt, 3-[(3cholamidopropyl)-dimethylammonio]propanesulfonate, and Lubrol detergent-solubilized preparations of the membrane-binding proteins, although these preparations could contain lipids as well. The barbiturate-GABA-benzodiazepine interactions are still present in the receptor. protein complex partially purified by column chromatography (Stephenson and Olsen, 1982). Separation of the benzodiazepine binding and barbiturate-sensitive picrotoxinin binding activity by column chromatography has been reported, however (Davis and Ticku, 1981). It is not yet known why treatment of the membranes with low levels of Triton X-100, while leaving the GABA binding intact, destroys the barbiturate enhancement, but it could be that the Triton X-100 removes protein or lipid components required for the interaction.

The pyrazolopyridines and barbiturates enhance GABA and benzodiazepine receptor binding specifically and do not affect the binding to brain membranes of radioactive ligands for dopamine, opiate, $\alpha$-adrenergic, muscarinic, or glycine receptors (Leeb-Lundberg and Olsen, 1982a; Meiners and Salama, 1982). The chemical specificity for barbiturate enhancement of GABA binding is very similar to that which we reported for the enhancement of benzodiazepine binding (Table V) and has been shown previously to correlate with hypnotic activity and the enhancement of GABA action (Bowery and Dray, 1978; Leeb-Lundberg et al., 1980). A similar effect of barbiturates on benzodiazepine binding has been reported by at least three other laboratories (Skolnick et al., 1981; Ticku, 1981; Asano and Ogasawara, 1981).

The barbiturate interaction with GABA receptor binding was suggested by the observation that the pyrazolopyridines enhance GABA binding (Placheta and Karobath, 1980), since the barbiturates resemble the pyrazolopyridines in causing a chloride-dependent, picrotoxinin-sensitive enhancement of benzodiazepine binding (Supavilai and Karobath, 1981; Leeb-Lundberg et al., 1981a). Pyrazolopyridines and barbiturates overlap in their pharmacological actions (both are anxiolytic; both enhance GABA responses; Study and Barker, personal communication), but they do not coincide (pyrazolopyridines are not very sedative; Meiners and Salama, 1982). The similar effects in vitro appear related to the actions of these two classes of drugs on the GABA/benzodiazepine receptor system; it seems reasonable that barbiturates have additional actions in vivo which are not shared with pyrazolopyridines. Furthermore, the in vitro effects of barbiturates and pyrazolopyridines are not equal, differing, for example, in their sensitivity to bicuculline with regard to their enhancement of benzodiazepine binding (Leeb-Lundberg et al., 1981a) and in the interaction with subpopulations of benzodiazepine receptors differing in affinity for $\beta$-carbolines and triazolopyridazine ligands (Leeb-Lundberg and Olsen, 1982b).

Although some of the barbiturates which enhance GABA and benzodiazepine activity are excitatory agents, they are depressants in addition (Huang and Barker, 1980; Knabe et al., 1978). In fact, all of the active compounds have depressant activity and GABA-enhancing physiological activity which correlates with their activity in vitro to enhance GABA binding (DMBB $>$ secobarbital $>$ pentobarbital $=(+)$-hexobarbital $>(-)$-mephobarbital $=$ amobarbital $>(-)$-hexobarbital $>(+)$-mephobarbital $=$ phenobarbital $=$ metharbital $=$ barbital $)$, as previously discussed in detail (Olsen and Leeb-Lundberg, 1981; Leeb-Lundberg and Olsen, 1982a). A relationship between the barbiturate enhancement of GABA binding measured biochemically and the barbiturate enhancement of the physiological action of GABA is strongly suggested. An understanding of the exact relationship of the excitatory barbiturates in this system will require more information, however.

Another "excitatory" barbiturate, 5-ethyl-5-(3-methyl but-2-enyl)barbiturate, was reported by Willow and Johnston (1981a) to enhance GABA binding as potently and efficaciously as pentobarbital. Those workers also reported that phenobarbital enhances GABA binding to the same degree (about a 40\% maximal effect) as pentobarbital although with lower potency (Willow and Johnston, 1981a). At higher concentrations, pentobarbital was observed to reverse its enhancement, and when the membranes were washed with low levels of Triton X-100, only an inhibition was observed, suggesting that two separate effects are involved (Willow and Johnston, 1981c). In our hands, using a different membrane preparation as described above, phenobarbital gave no significant enhancement but did give a weak and probably nonspecific inhibition at supramillimolar concentrations. Triton X100 treatment did eliminate the enhancement of GABA binding by the active barbiturates.

We observed that phenobarbital enhances benzodiazepine binding only slightly but, at $200 \mu \mathrm{M}$, competitively inhibits the enhancement of benzodiazepine binding by pentobarbital, indicating that phenobarbital binds to the same sites as pentobarbital, but in a different manner (Leeb-Lundberg and Olsen, 1982a). Since some other nonbarbiturate anticonvulsant agents had a similar, albeit weak, effect (Leeb-Lundberg et al., 1981b), the different effects of barbiturates used primarily for anticonvulsant activity (e.g., phenobarbital) and those used primarily for hypnotic activity (e.g., pentobarbital) might be related to qualitative differences observed between the two types of drugs in physiological studies of barbiturate action (Schulz and Macdonald, 1981; Simmonds, 1981). The relevance of anticonvulsant drug interactions with the GABA receptor system also will require further study.

The anion specificity for the enhancement of GABA binding by barbiturates also agrees with that seen for barbiturate (Leeb-Lundberg et al., 1980) and pyrazolopyridine (Supavilai and Karobath, 1981) enhancement of benzodiazepine binding as well as with the anion enhancement of base line benzodiazepine binding (Costa et 
al., 1978). This anion specificity has been shown (Costa et al., 1978; Leeb-Lundberg et al., 1980) to correlate with that of chloride channels involved in postsynaptic inhibitory potentials in spinal cord (Araki et al., 1961) and hippocampus (Eccles et al., 1977), inhibitory potentials which also are potentiated by barbiturates (Nicoll et al., 1975). This correspondence in anion specificity seems unlikely to be coincidental and provides further evidence that the in vitro interaction of barbiturates with GABA receptor binding is related to some pharmacological effects of these drugs.

The inhibition by micromolar picrotoxinin of barbiturate enhancement of GABA and benzodiazepine binding is also consistent with the interaction at the GABA receptor-ionophore complex. Barbiturates (Ticku and Olsen, 1978) and pyrazolopyridines (Leeb-Lundberg et al., 1981a) inhibit the binding of $\left[{ }^{3} \mathrm{H}\right]$ dihydropicrotoxinin at concentrations similar to those affecting GABA and benzodiazepine binding. Since there is not a very good correlation between barbiturate potencies in the latter assays and their inhibition of picrotoxinin binding (LeebLundberg and Olsen, 1982a; Olsen and Leeb-Lundberg, 1981), it appears that the picrotoxinin-sensitive barbiturate receptor site which is coupled to the GABA.benzodiazepine receptor complex is a subpopulation of sites labeled by radioactive picrotoxinin.

An interesting brain regional variation was observed for the barbiturate enhancement of GABA receptor binding. Although GABA binding is equal or greater in cerebellum than in cerebral cortex, barbiturate enhancement of GABA binding is much less in cerebellum than in cortex and therefore does not correlate with overall GABA binding. The enhancement may correspond instead with the presence of a subpopulation of GABA binding sites, perhaps of low affinity for GABA, which is associated with barbiturate receptor sites. This subpopulation seems to correspond in brain regional distribution with the fraction of barbiturate-enhanced benzodiazepine binding sites which is sensitive to the GABA receptor antagonist bicuculline and thus apparently associated with GABA receptors (Olsen and Leeb-Lundberg, 1981; Leeb-Lundberg and Olsen, 1981, 1982b).

Barbiturates enhanced GABA receptor binding using five different radioactive ligands. The barbiturate effects on GABA receptor binding were not significantly different at $37^{\circ} \mathrm{C}$ compared to $0^{\circ} \mathrm{C}$, using $\left[{ }^{3} \mathrm{H}\right] \mathrm{GABA}$ or $\left[{ }^{3} \mathrm{H}\right]$ muscimol as the ligand. The more physiological temperature has been found to reveal a chloride potentiation of GABA enhancement of benzodiazepine binding (Ehlert et al., 1981), a picrotoxinin blockade of GABA enhancement of benzodiazepine binding (Karobath et al., 1981), and an enhancement of benzodiazepine binding by certain GABA analogues, such as $\mathrm{P} 4 \mathrm{~S}$, which do not show the effect at $0^{\circ} \mathrm{C}$ in chloride-free medium (Supavilai and Karobath, 1980). Whereas the base line binding with all ligands was almost the same at $0^{\circ} \mathrm{C}$ and $37^{\circ} \mathrm{C}$, the enhancement of $\left[{ }^{3} \mathrm{H}\right] \mathrm{P} 4 \mathrm{~S}$ binding by pentobarbital was much greater at $37^{\circ} \mathrm{C}$ than at $0^{\circ} \mathrm{C}$. It may be that this difference is related to the temperature effect observed for the P4S interaction with benzodiazepine binding ( $\mathrm{Su}$ pavilai and Karobath, 1980). This provides another example of differences between GABA analogues in in vitro binding studies despite an apparently identical physio- logical action in vivo (Krogsgaard-Larsen et al., 1981). These intriguing differences may provide clues to the action of these substances at the receptor level.

Note added in proof. Other reports with similar results have appeared since the writing of this work (Whittle and Turner, 1982; Supavila et al., 1982).

\section{References}

Araki, T., M. Ito, and D. Oscarsson (1961) Anion permeability of the synaptic and nonsynaptic motoneurone membrane. J. Physiol. (Lond.) 159: 410-435.

Asano, T., and N. Ogasawara (1981) Chloride-dependent stimulation of GABA and benzodiazepine receptor binding by pentobarbital. Brain Res. 225: 212-216.

Blaustein, M. P. (1968) Barbiturates block sodium and potassium conductance increase in voltage-clamped lobster axons. J. Gen. Physiol. 51: 293-307.

Bowery, N. G., and A. Dray (1978) Reversal of the action of amino acid antagonists by barbiturates and other hypnotic drugs. Br. J. Pharmacol. 63: 197-215.

Costa, T., D. Rodbard, and C. Pert (1978) Is the benzodiazepine receptor coupled to a chloride ion channel? Nature 277: 315317.

Davis, W. C., and M. K. Ticku (1981) Picrotoxinin and diazepam bind to two distinct proteins: Further evidence that pentobarbital may act at the picrotoxinin site. J. Neurosci. 1: 10361042.

Eccles, J., R. A. Nicoll, T. Oshima, and F. J. Rubia (1977) The anionic permeability of the inhibitory postsynaptic membrane of hippocampal pyramidal cells. Proc. R. Soc. Lond. (Biol.) 198: 345-361.

Ehlert, F. J., W. R. Roeske, C. Braestrup, S. H. Yamamura, and H. I. Yamamura (1981) $\gamma$-Aminobutyric acid regulation of the benzodiazepine receptor: Biochemical evidence for pharmacologically different effects of benzodiazepines and propyl $\beta$-carboline-3-carboxylate. Eur. J. Pharmacol. 70: 593596.

Enna, S. J., and S. H. Snyder (1975) Properties of $\gamma$-aminobutyric acid (GABA) receptor binding in rat brain synaptic membrane fractions. Brain Res. 100: 81-97.

Greenlee, D. V., P. C. Van Ness, and R. W. Olsen (1978) Endogenous inhibitor of GABA binding in mammalian brain. Life Sci. 22: 1653-1662.

Guidotti, A., G. Toffano, and E. Costa (1978) An endogenous protein modulates the affinity of GABA and benzodiazepine receptors in rat brain. Nature 275: 553-555.

Haefely, W., P. Polc, R. Schaffner, H. H. Keller, L. Pieri, and H. Möhler (1979) Facilitation of GABAergic transmission by drugs. In GABA-Neurotransmitters, P. Krogsgaard-Larsen, J. Scheel-Kruger, and H. Kofod, eds., pp. 357-375, Munksgaard, Copenhagen.

Huang, L. -Y. M., and J. L. Barker (1980) Pentobarbital: Stereospecific actions of $(+)$ and $(-)$ isomers revealed on cultured mammalian neurons. Science 297: 195-197.

Ito, Y., and K. Kuriyama (1982) Some properties of solubilized GABA receptor. Brain Res. 236: 351-363.

Karobath, M., G. Drexler, and P. Supavilai (1981) Modulation by picrotoxinin and IPTBO of $\left[{ }^{3} \mathrm{H}\right]$-flunitrazepam binding to the GABA/benzodiazepine receptor complex of rat cerebellum. Life Sci. 28: 307-313.

Knabe, V. J., W. Rummel, H. P. Buch, and N. Franz (1978) Optisch aktive Barbiturate. Synthese, Konfiguration und pharmakologische wirkung. Arzneimittelforsch. 28: 10481056.

Krogsgaard-Larsen, P., A. Snowman, S. C. Lummis, and R. W. Olsen (1981) Characterization of the binding of the GABA agonist $\left[{ }^{3} \mathrm{H}\right]$ piperidine-4-sulphonic acid to bovine brain synaptic membranes. J. Neurochem. 37: 401-409. 
Leeb-Lundberg, F., and R. W. Olsen (1981) Brain regional variation in benzodiazepine and GABA receptor association. Soc. Neurosci. Abstr. 7: 738.

Leeb-Lundberg, F., and R. W. Olsen (1982a) Interactions of barbiturates of various pharmacological categories with benzodiazepine receptors. Mol. Pharmacol. 21: 320-328.

Leeb-Lundberg, F., and R. W. Olsen (1982b) Multiple coupling state model for the GABA-benzodiazepine-barbiturate receptor chloride-ionophore complex. Fed. Proc. 41: 1328.

Leeb-Lundberg, F., A. Snowman, and R. W. Olsen (1980) Barbiturate receptor sites are coupled to benzodiazepine receptors. Proc. Natl. Acad. Sci. U. S. A. 77: 7468-7472.

Leeb-Lundberg, F., A. Snowman, and R. W. Olsen (1981a) Perturbation of benzodiazepine receptor binding by pyrazolopyridines involves picrotoxinin/barbiturate receptor sites. J. Neurosci. 1: 471-477.

Leeb-Lundberg, F., A. Snowman, and R. W. Olsen (1981b) Interaction of anticonvulsants with the barbiturate/benzodiazepine/GABA receptor complex. Eur. J. Pharmacol. 72: $125-129$.

Leeb-Lundberg, F., C. Napias, and R. W. Olsen (1981c) Dihydropicrotoxinin binding sites in mammalian brain: Interaction with convulsant and depressant benzodiazepines. Brain Res. 216: 399-408.

Lowry, O. H., N. J. Rosebrough, A. L. Farr, and R. J. Randall (1951) Protein measurement with the Folin phenol reagent. J. Biol. Chem. 193: 265-275.

Matsumoto, K., and H. Fukuda (1982) Stimulatory and protective effects of benzodiazepines on GABA receptors labeled with [ $\left.{ }^{3} \mathrm{H}\right]$ muscimol. Life Sci. 30: 935-943.

Meiners, B. A., and A. I. Salama (1982) Enhancement of benzodiazepine and GABA binding by the novel anxiolytic tracazolate. Eur. J. Pharmacol. 78: 315-322.

Napias, C., M. O. Bergman, P. C. Van Ness, D. V. Greenlee, and $R$. W. Olsen (1980) GABA binding in mammalian brain: Inhibition by endogenous GABA. Life Sci. 27: 1001-1011.

Nicoll, R. A., and J. M. Wojtowicz (1980) The effects of pentobarbital and related compounds on frog motoneurons. Brain Res. 191: 225-237.

Nicoll, R. A., J. C. Eccles, T. C. Oshima, and F. Rubia (1975) Prolongation of hippocampal inhibitory post-synaptic potentials by barbiturates. Nature 258: 625-627.

Olsen, R. W. (1981) GABA-benzodiazepine-barbiturate receptor interactions. J. Neurochem. 37: 1-13.

Olsen, R. W., and F. Leeb-Lundberg (1981) Convulsant and anticonvulsant drug binding sites related to the GABA receptor/ionophore system. In Neurotransmitters, Seizures and Epilepsy, P. L. Morselli, K. G. Lloyd, W. Löscher, B. S. Meldrum, and E. H. Reynolds, eds., pp. 151-163, Raven Press, New York.

Olsen, R. W., M. K. Ticku, D. Greenlee, and P. Van Ness (1979) GABA receptor and ionophore binding sites: Interactions with various drugs. In GABA-Neurotransmitters, P. Krogsgaard-Larsen, J. Scheel-Kruger, and H. Kofod, eds., pp. 165178, Munksgaard, Copenhagen.

Olsen, R. W., A. Snowman, and F. Leeb-Lundberg (1981a) Barbiturates enhance GABA receptor binding in mammalian brain membranes in vitro. Fed. Proc. 40: 309.

Olsen, R. W., M. O. Bergman, P. C. Van Ness, S. C. Lummis, A. E. Watkins, C. Napias, and D. V. Greenlee (1981b) $\gamma$-Aminobutyric acid receptor binding in mammalian brain: Heterogeneity of binding sites. Mol. Pharmacol. 19: 217-227.

Placheta, P., and M. Karobath (1980) In vitro modulation by SQ 20009 and SQ 65396 of GABA receptor binding in rat CNS membranes. Fur. II. Pharmacol. 62: 225-228.

Richards, C. D. (1972) On the mechanism of barbiturate anaesthesia. J. Physiol. (Lond.) 227: 749-767.

Schulz, D. W., and R. L. Macdonald (1981) Barbiturate enhancement of GABA-modulated inhibition and activation of chloride ion conductance: Correlation with anticonvulsants and anesthetic actions. Brain Res. 209: 177-188.

Simmonds, M. A. (1981) Distinction between the effects of barbiturates, benzodiazepines and phenytoin on responses to $\gamma$-aminobutyric acid receptor activation and antagonism by bicuculline and picrotoxinin. Br. J. Pharmacol. 73: 739-747.

Skerritt, J. H., M. Willow, and G. A. R. Johnston (1982) Diazepam enhancement of low affinity GABA binding to rat brain membranes. Neurosci. Lett. 29: 63-66.

Skolnick, P., V. Moncada, J. L. Barker, and S. M. Paul (1981) Pentobarbital: Dual actions to increase brain benzodiazepine receptor affinity. Science 211: 1448-1450.

Squires, R. F., and C. Braestrup (1977) Benzodiazepine receptors in rat brain. Nature 266: $732-734$.

Stephenson, F. A., and R. W. Olsen (1982) Solubilization by CHAPS detergent of barbiturate-enhanced benzodiazepineGABA receptor complex. J. Neurochem., in press.

Stephenson, F. A., A. E. Watkins, and R. W. Olsen (1982) Physicochemical characterization of detergent-solubilized $\gamma$ aminobutyric acid and benzodiazepine receptor proteins from bovine brain. Eur. J. Biochem. 123: 291-298.

Study, R. E., and J. L. Barker (1981) Diazepam and (-)pentobarbital: Fluctuation analysis reveals different mechanisms for potentiation of $\gamma$-aminobutyric acid responses in cultured central neurons. Proc. Natl. Acad. Sci. U. S. A. 78: $7180-7184$.

Supavilai, P., and M. Karobath (1980) The effect of temperature and chloride ions on the stimulation of $\left[{ }^{3} \mathrm{H}\right]$ flunitrazepam binding by THIP and PSA. Neurosci. Lett. 19: 337-341.

Supavilai, P., and M. Karobath (1981) Action of pyrazolopyridines as modulators of $\left[{ }^{3} \mathrm{H}\right]$ flunitrazepam binding to the GABA/benzodiazepine receptor complex of the cerebellum. Eur. J. Pharmacol. 70: 183-193.

Supavila, P., A. Mannonen, and M. Karobath (1982) Modulation of GABA binding sites by CNS depressants and CNS convulsants. Neurochem. Int. 4: 259-268.

Tallman, T. F., S. M. Paul, P. Skolnick, and D. W. Gallager (1980) Receptors for the age of anxiety: Pharmacology of the benzodiazepines. Science 207: 274-281.

Ticku, M. K. (1981) Interaction of depressant, convulsant and anticonvulsant barbiturates with $\left[{ }^{3} \mathrm{H}\right]$ diazepam binding site at the benzodiazepine-GABA-receptor-ionophore complex. Biochem. Pharmacol. 30: 1573-1579.

Ticku, M. K., and R. W. Olsen (1978) Interaction of barbiturates with dihydropicrotoxinin binding sites related to the GABA receptor-ionophore system. Life Sci. 22: 1643-1652.

Whittle, S. R. and A. J. Turner (1982) Differential effects of sedative and anticonvulsant barbiturates on specific $\left[{ }^{i 3} \mathrm{H}\right]$ GABA binding to membrane preparations from rat brain cortex. Biochem. Pharmacol. 31: 2891- 2895.

Willow, M. (1981) A comparison of the actions of pentobarbital and etomidate on $\left[{ }^{3} \mathrm{H}\right] \mathrm{GABA}$ binding to crude synaptosomal rat brain membranes. Brain Kes. 220: 427-431.

Willow, M., and G. A. R. Johnston (1980) Enhancement of GABA binding by pentobarbitone. Neurosci. Lett. 18: 323327.

Willow, M., and G. A. R. Johnston (1981a) Enhancement by anesthetic and convulsant barbiturates of GABA binding to rat brain synaptosomal membranes. J. Neurosci. 1: 364-367.

Willow, M., and G. A. R. Johnston (1981b) Pentobarbitone slows the dissociation of GABA from rat brain synaptosomal binding sites. Neurosci. Lett. 23: 71-74.

Willow, M., and G. A. R. Johnston (1981c) Dual action of pentobarbitone on GABA binding. Role of binding site integrity. J. Neurochem. 37: 1291-1294.

Zukin, S. R., A. B. Young, and S. H. Snyder (1974) Gammaaminobutyric acid binding to receptor sites in rat central nervous system. Proc. Natl. Acad. Sci. U. S. A. 71: 4802-4807. 